\title{
Serum folic acid activity (L. casei) in Sephadex gel chromatography
}

\author{
T. MARKKANEN, R.-L. PAJULA, P. HIMANEN, AND S. VIRTANEN \\ From the Departments of Medical Microbiology and Medicine, University of Turku, Turku, Finland
}

SYNOPSIS The folic acid activity (FAA) of the protein zone in DEAE Sephadex A-50 chromatography of normal serum showed the following distribution: most (about 40\%) was eluted with protein zone IV (alpha-2-macroglobulin), about 33\% with protein zones II-III (transferrin), and the balance with zone V (albumin). In healthy human subjects the variations were relatively small. The repeatability of the chromatography in an individual was good.

Towards the end of pregnancy the binding of FAA to protein zones II-III increased, while that to zone IV decreased. The return to normal started a few days after delivery.

The binding to zones II-III was greatly increased in patients with pernicious anaemia but no neuropathy. It became normal during $\mathbf{B}_{\mathbf{1 2}}$ therapy. If the patient had neuropathy, his FAA chromatogram was close to normal. During therapy the amount of unbound FAA decreased rapidly.

The use of diphenylhydantoin increased the binding of FAA to protein zone I and to zones II-III. In these patients the binding to protein zone IV was slighter than normal.

The total folic acid activity of the serum in health and in various diseases of man has been extensively discussed in the medical literature. These reports have almost completely neglected the possibility of folic acid activity being bound to the serum proteins. However, Toennies, Usdin, and Phillips (1956) found in their studies that the plasma factor was present in the Cohn fractions IV $+V$ of the plasma. It was also present in the glycoproteins, lipoproteins, mucoproteins, and other special proteins. Attention was also focused on the part played by subfraction I V-4. Condit and Grob (1958) found that the electrophoretic mobility of folic acid activity was greater than that of albumin. The same result was reported later by Elsborg (1972). Johns, Sperti, and Burgen (1961) considered there was little or no free folic acid activity in the fasting plasma. Injected tritiumlabelled folic acid activity in plasma was $64 \%$ protein-bound. Neal and Williams (1965) added tritiated folic acid to rat serum and studied its behaviour in electrophoresis. Folic acid activity migrated towards the anode faster than albumin and only small amounts of radioactivity were found in the protein fractions. Unbound folic acid activity was found to run in advance of the albumin, occupying a similar zone to that of natural folate. Traces of

Received for publication 3 May 1973. folic acid activity were found to be present in the albumin fraction but not in the globulin fractions. The authors found that the binding of the folic acid activity to serum was non-specific.

In addition to the above, there have been mainly theoretical assumptions that folic acid activity in the serum could also be bound to proteins (Klipstein, 1964; Sevitt and Hoffbrand, 1969; Banerjee and Chatterjea, 1971; Fleming, 1972). In our laboratory (Markkanen, 1968) we have subsequently been able to show conclusively that it is possible, in suitable conditions, to divide the total serum folic acid activity by gel chromatography into a so-called free fraction and a protein-bound fraction, and that the latter perhaps could still be divided into several subfractions. This finding was later confirmed in principle (Retief and Huskisson, 1969; Retief and Huskisson, 1970a and b; Elsborg, 1972).

In the following, folic acid activity carried by serum proteins is analysed further, trying to ascertain the proteins with which folic acid activity is eluted from a chromatography column in experimental conditions.

\section{Materials and Methods}

In the procedure for isolating the carrier proteins, we adopted techniques different from those described 
earlier (Markkanen, 1968). DEAE Sephadex A-50 gel (Pharmacia Fine Chemicals AB, Uppsala, Sweden) was used for chromatography, and a thin layer of Sephadex G-25 coarse gel (the same manufacturer) was placed at the bottom of the column. The last-mentioned gel was put to swell for three hours in distilled water, and DEAE Sephadex A-50 for three days in the specific packaging buffer, at room temperature, protected against impurities of the air. After the chromatographic process the same gel was regenerated by elution with $2.5 \mathrm{M} \mathrm{NaCl}$ buffer solution and $0 \cdot 1 \mathrm{~N} \mathrm{NaOH}$. Subsequently the gel was rinsed with distilled water and retransferred for a fresh packing into packaging (buffer column size, $40 \times 500 \mathrm{~mm}$ ).

\section{BUFFERS}

The basic buffer was $0.05 \mathrm{M}$ sodium phosphate buffer, pH 7.0 (solution A: $0.5 \mathrm{M} \mathrm{Na}_{2} \mathrm{HPO}_{4}, 71 \mathrm{~g} / 1$; solution B $0.5 \mathrm{M} \mathrm{NaH}_{2} \mathrm{PO}_{4} \times \mathrm{H}_{2} \mathrm{O}, 69 \mathrm{~g} / 1$. Solution $A$ was added to solution $\mathrm{B}$, and the $\mathrm{pH}$ was adjusted to 7.0 at a dilution of $1: 10$ ). The packaging buffer was $0.05 \mathrm{M}$ sodium phosphate buffer, $\mathrm{pH} 7 \cdot 0$, with $0.02 \mathrm{M} \mathrm{NaCl}$ solution. The elution buffer consisted of solutions obtained by adding $\mathrm{NaCl}$ to the basic buffer: $0.05,0 \cdot 10,0 \cdot 15,0 \cdot 20,0 \cdot 30,0.40$, and $0.50 \mathrm{M}$.

To eliminate bacterial contamination, which is highly detrimental to chromatography of folic acid activity, all solutions were sterilized for $15 \mathrm{~min}$ at $120^{\circ} \mathrm{C}$ in an autoclave and kept in stoppered flasks in the refrigerator at $+4^{\circ} \mathrm{C}$. In this way, too high bacterial invasion into chromatography gel during the run could be prevented. All the chemicals represented the purity degree 'proanalysi' (Merck).

\section{SERUM CHROMATOGRAPHY}

Forty $\mathrm{ml}$ fresh serum was applied to the column. After serum absorption, $200 \mathrm{ml}$ of the packaging buffer containing $0.02 \mathrm{M} \mathrm{NaCl}$ was applied to the column.

The serum was eluated from the column, by stages, with buffer solutions containing $\mathrm{NaCl}$ concentrations increasing from 0.02 to $0.50 \mathrm{M}$. The elution buffers, $250 \mathrm{ml}$ of each, were added, by pairs, consecutively to the mixing flask (the true elution flask) andito the subsidiary flask. The flasks were connected with tubing.

Fractionation was carried out at $+10^{\circ} \mathrm{C}$. The $10-\mathrm{ml}$ fractions were collected with an automatic collector (LKB-RadiRac). The rate of elution was $50 \mathrm{ml} / \mathrm{hr}$ with fresh gel and $100 \mathrm{ml} / \mathrm{hr}$ with regenerated gel. The fractions, in protected tubes, were immediately placed in a dark refrigerator and their treatment was started at once.

Proteins were determined by means of the biuret reaction, as described previously, and the folic acid activity of the fractions and the starch gel plates were determined microbiologically with the $L$. casei method, also described previously (Markkanen and Peltola, 1971).

After chromatography the fractions of protein groups were concentrated in the following way.

The fractions were pipetted into dialysis bags which were submerged in a dextran $\mathrm{T}-500$ solution $(15 \%$ in water; Pharmacia, Uppsala) and placed into a refrigerator for three days. During this time the excessive electrolytes and the volume-increasing fluid were dialysed from the fractions into the dextran. The fractions were in this way concentrated to about one-fifth of their original volume. In detail, the concentration was carried out as described before (Grogan and Roboz, 1955).

After the concentration the protein components of the fractions were identified by immunoelectrophoresis (Wieme, 1965) and by the immunodiffusion test (Raunio, 1968), also described in detail previously.

The proteins of the concentrated fractions were separated by horizontal gel electrophoresis, using hydrolysed starch (Connaught Medical Laboratories, Toronto) and the discontinuous tris-borate buffer system (Hitzig, Butler, Cottier, Hess, and Muralt, 1963). One plate was stained with amido black $10 \mathrm{~B}$ (Uriel, 1964). The part of the unstained plate corresponding to the unidentified and standard protein (Behringwerke AG) was cut off for determination of folic acid activity.

\section{Results}

Figures 1 and 2 show the typical protein and folic acid activity chromatograms of a healthy man and woman. Five protein zones can be distinguished: zone I, on immunological analysis, contains gamma globulin and hardly any appreciable folic acid activity in healthy subjects, zone II contains some fraction of gamma globulin plus transferrin; folic acid activity is carried by transferrin in electrophoresis towards the cathode. Zone III contains only transferrin, and binds a great deal of folic acid activity per protein unit. The peak of zone IV contains purely alpha-2-macroglobulin which binds a great deal of folic acid activity. Zone $\mathrm{V}$ contains albumin which has a low folic acid activity-binding capacity. Table I shows that in chromatograms $22-60 \%$ of the total serum folic acid activity is eluted with the proteins. The highest percentage is eluted in zone IV (41\%), next highest in zones II-III $(33 \%)$, and almost all the balance in zone V $(22 \%)$. In healthy people folic acid activity is hardly ever found in zone $\mathrm{I}$.

The repeatability of the chromatograms is excel- 


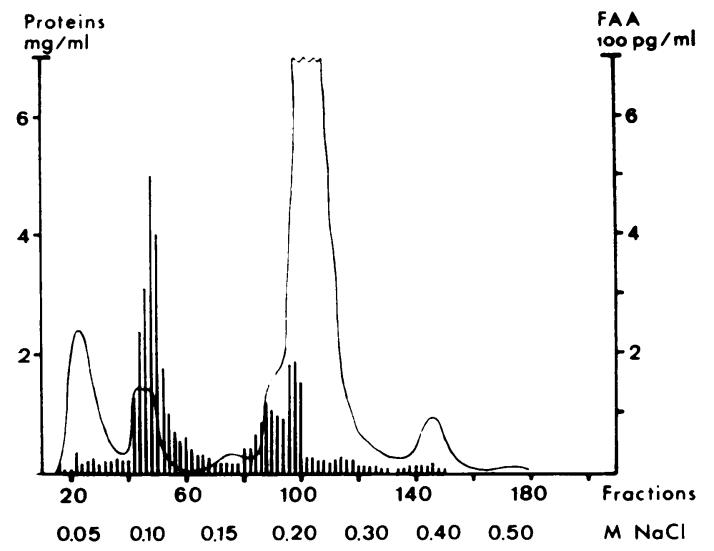

Fig 1 A typical chromatogram of a normal subject, a 19-year-old healthy sportswoman.

\begin{tabular}{|c|c|c|c|}
\hline Protein Zones & Mean & $S D$ & Range \\
\hline $\begin{array}{l}\text { Whole serum } \\
\text { Proteins }(\mathrm{mg} / \mathrm{ml}) \\
\text { FAA }(\mathrm{ng} / \mathrm{ml}) \\
\text { FAA/protein }(\mathrm{ng} / \mathrm{g}) \\
\text { Protein-bound FAA }(0,0)\end{array}$ & $\begin{array}{r}78 \cdot 3 \\
4 \cdot 1 \\
20 \cdot 6 \\
41 \cdot 0\end{array}$ & $\begin{array}{r}6 \cdot 7 \\
1 \cdot 3 \\
5 \cdot 2 \\
19 \cdot 5\end{array}$ & $\begin{array}{rr}70 \cdot 8-88 \cdot 4 \\
2 \cdot 0- & 5 \cdot 8 \\
11 \cdot 6-27 \cdot 2 \\
22 \cdot 0-82 \cdot\end{array}$ \\
\hline $\begin{array}{l}\text { Zone I } \\
\text { Proteins }(\%) \\
\text { FAA }(\%) \\
\text { FAA } / \text { protein }(\mathrm{pg} / \mathrm{mg})\end{array}$ & $\begin{array}{r}13 \cdot 0 \\
3 \cdot 0 \\
4 \cdot 0\end{array}$ & $\begin{array}{l}2 \cdot 8 \\
2 \cdot 6 \\
4 \cdot 3\end{array}$ & $\begin{array}{rr}10 \cdot 0-17 \cdot 0 \\
0 \cdot 0- & 8 \cdot 0 \\
0 \cdot 0-12 \cdot 0\end{array}$ \\
\hline $\begin{array}{l}\text { Zone } I I \\
\text { Proteins }(\%) \\
\text { FAA }(\%) \\
\text { FAA } / \text { protein }(\mathrm{pg} / \mathrm{mg})\end{array}$ & $\begin{array}{r}7 \cdot 0 \\
21 \cdot 0 \\
65 \cdot 0\end{array}$ & $\begin{array}{r}1 \cdot 4 \\
8 \cdot 4 \\
48 \cdot 0\end{array}$ & $\begin{array}{r}5 \cdot 0-\quad 9 \cdot 0 \\
10 \cdot 0-38 \cdot 0 \\
40 \cdot 0-185 \cdot 0\end{array}$ \\
\hline $\begin{array}{l}\text { Zone } I I I \\
\text { Proteins }(\%) \\
\text { FAA }(\%) \\
\text { FAA } / \text { protein }(\mathrm{pg} / \mathrm{mg})\end{array}$ & $\begin{array}{r}2 \cdot 0 \\
12 \cdot 0 \\
128 \cdot 0\end{array}$ & $\begin{array}{r}1 \cdot 3 \\
3 \cdot 0 \\
76 \cdot 0\end{array}$ & $\begin{array}{r}1 \cdot 0-4 \cdot 0 \\
8 \cdot 0-17 \cdot 0 \\
63 \cdot 0-261 \cdot 0\end{array}$ \\
\hline $\begin{array}{l}\text { Zone IV } \\
\text { Proteins }(\%) \\
\text { FAA }(\%) \\
\text { FAA } / \text { protein }(\mathrm{pg} / \mathrm{mg})\end{array}$ & $\begin{array}{r}7 \cdot 0 \\
41 \cdot 0 \\
122 \cdot 0\end{array}$ & $\begin{array}{r}2 \cdot 2 \\
16 \cdot 6 \\
35 \cdot 8\end{array}$ & $\begin{array}{r}5 \cdot 0-11 \cdot 0 \\
29 \cdot 0-63 \cdot 0 \\
72 \cdot 0-167 \cdot 0\end{array}$ \\
\hline $\begin{array}{l}\text { Zone } V \\
\text { Proteins }(\%) \\
\text { FAA }(\%) \\
\text { FAA } / \text { protein }(\mathrm{pg} / \mathrm{mg})\end{array}$ & $\begin{array}{r}70 \cdot 0 \\
22 \cdot 0 \\
6 \cdot 0\end{array}$ & $\begin{array}{r}3 \cdot 3 \\
11 \cdot 4 \\
3 \cdot 3\end{array}$ & $\begin{array}{r}64.0-76.0 \\
7.0-41 \cdot 0 \\
3.0-13.0\end{array}$ \\
\hline
\end{tabular}

Table I Numerical values for the chromatograms of nine healthy test subjects (mean age 23 years, seven men and two women). Protein zones marked I- $V$ as shown in figures 1 and 2 .

lent for any one and the same healthy person. The chromatogram of an individual, in identical conditions, practically always has the same appearance, and although there are slight numerical variations, these are not significant (table II). Studies of the influence of various factors and diseases, however, reveal chromatographic changes in folic acid activity that are of an entirely different order of magnitude.

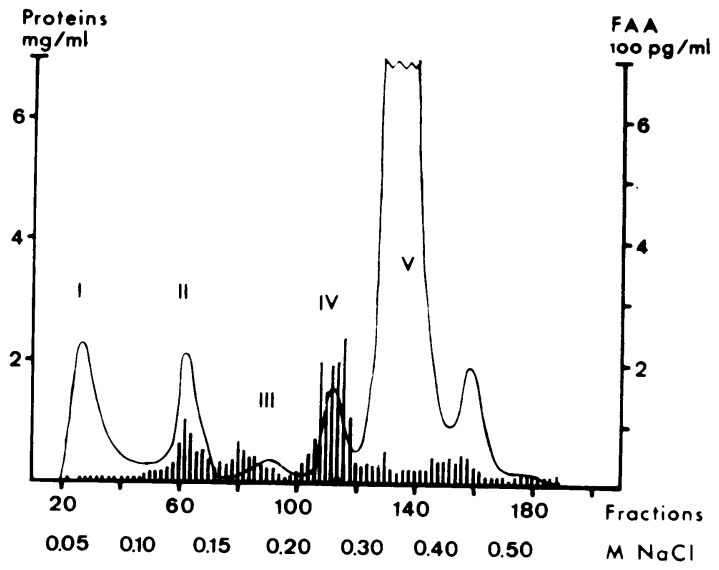

Fig 2 A typical chromatogram of a normal subject, a 23-year-old man.

\begin{tabular}{|c|c|c|c|}
\hline Protein Zones & Mean & $S D$ & Range \\
\hline $\begin{array}{l}\text { Whole serum } \\
\text { Proteins }(\mathrm{mg} / \mathrm{mi}) \\
\text { FAA }(\mathrm{ng} / \mathrm{ml}) \\
\text { FAA/protein }(\mathrm{ng} / \mathrm{g}) \\
\text { Protein-bound FAA }(\%)\end{array}$ & $\begin{array}{r}704 \\
2 \cdot 8 \\
19 \cdot 7 \\
49 \cdot 3\end{array}$ & $\begin{array}{l}1.9 \\
0.6 \\
3 \cdot 9 \\
3 \cdot 0\end{array}$ & $\begin{array}{rr}68 \cdot 5-72 \cdot 3 \\
2 \cdot 2- & 3 \cdot 4 \\
15 \cdot 8- & 23 \cdot 6 \\
46 \cdot 0-52 \cdot 0\end{array}$ \\
\hline $\begin{array}{l}\text { Zone I } \\
\text { Proteins }(\%) \\
\text { FAA }(\%) \\
\text { FAA } / \text { protein }(\mathrm{pg} / \mathrm{mg})\end{array}$ & $\begin{array}{r}10 \cdot 0 \\
7 \cdot 0 \\
13 \cdot 0\end{array}$ & $\begin{array}{l}0 \cdot 8 \\
4 \cdot 0 \\
6 \cdot 0\end{array}$ & $\begin{array}{l}9 \cdot 0-11 \cdot 0 \\
3 \cdot 0-11 \cdot 0 \\
7 \cdot 0-18 \cdot 0\end{array}$ \\
\hline $\begin{array}{l}\text { Zone } I I \\
\text { Proteins }(\%) \\
\text { FAA }(\%) \\
\text { FAA } / \text { protein }(\mathrm{pg} / \mathrm{mg})\end{array}$ & $\begin{array}{r}6 \cdot 0 \\
30 \cdot 0 \\
90 \cdot 0\end{array}$ & $\begin{array}{r}0.5 \\
7 \cdot 0 \\
26 \cdot 0\end{array}$ & $\begin{array}{r}6 \cdot 0-\quad 7 \cdot 0 \\
23 \cdot 0-37 \cdot 0 \\
64 \cdot 0-116 \cdot 0\end{array}$ \\
\hline $\begin{array}{l}\text { Zone } I I I \\
\text { Proteins }(\%) \\
\text { FAA }(\%) \\
\text { FAA } / \text { protein }(\mathrm{pg} / \mathrm{mg})\end{array}$ & $\begin{array}{r}1 \cdot 0 \\
11 \cdot 0 \\
172 \cdot 0\end{array}$ & $\begin{array}{r}0.4 \\
1 \cdot 0 \\
34 \cdot 0\end{array}$ & $\begin{array}{rr}1 \cdot 0- & 2 \cdot 0 \\
10 \cdot 0-12 \cdot 0 \\
138 \cdot 0-206 \cdot 0\end{array}$ \\
\hline $\begin{array}{l}\text { Zone IV } \\
\text { Proteins }(\%) \\
\text { FAA }(\%) \\
\text { FAA } / \text { protein }(\mathrm{pg} / \mathrm{mg})\end{array}$ & $\begin{array}{r}5 \cdot 0 \\
34 \cdot 0 \\
122 \cdot 0\end{array}$ & $\begin{array}{r}0.8 \\
6 \cdot 0 \\
42 \cdot 0\end{array}$ & $\begin{array}{r}4 \cdot 0-6 \cdot 0 \\
28 \cdot 0-40 \cdot 0 \\
80 \cdot 0-164 \cdot 0\end{array}$ \\
\hline $\begin{array}{l}\text { Zone } V \\
\text { Proteins }(\%) \\
\text { FAA }(\%) \\
\text { FAA } / \text { protein }(\mathrm{pg} / \mathrm{mg})\end{array}$ & $\begin{array}{r}75 \cdot 0 \\
17 \cdot 0 \\
4 \cdot 0\end{array}$ & $\begin{array}{r}3.0 \\
10.0 \\
3.0\end{array}$ & $\begin{array}{rr}72 \cdot 0- & 78.0 \\
7 \cdot 0- & 27.0 \\
1.0- & 7.0\end{array}$ \\
\hline
\end{tabular}

Table II Follow-up study of the chromatograms of a healthy man of 23 to ascertain repeatability (protein zones as in fig 2). The test was carried out six times in nine months.

During pregnancy (figs 3 and 4) the protein binding of folic acid activity increases. A particularly distinct increase takes place in protein zones II-III (chromatograms A-B). At the same time there is a slight decrease in zone IV. Soon after delivery, some of the folic acid activity in zones II-III and zone V disappears (chromatograms C-D).

The following numerical changes during therapy were recorded in the patients with pernicious anaemia 

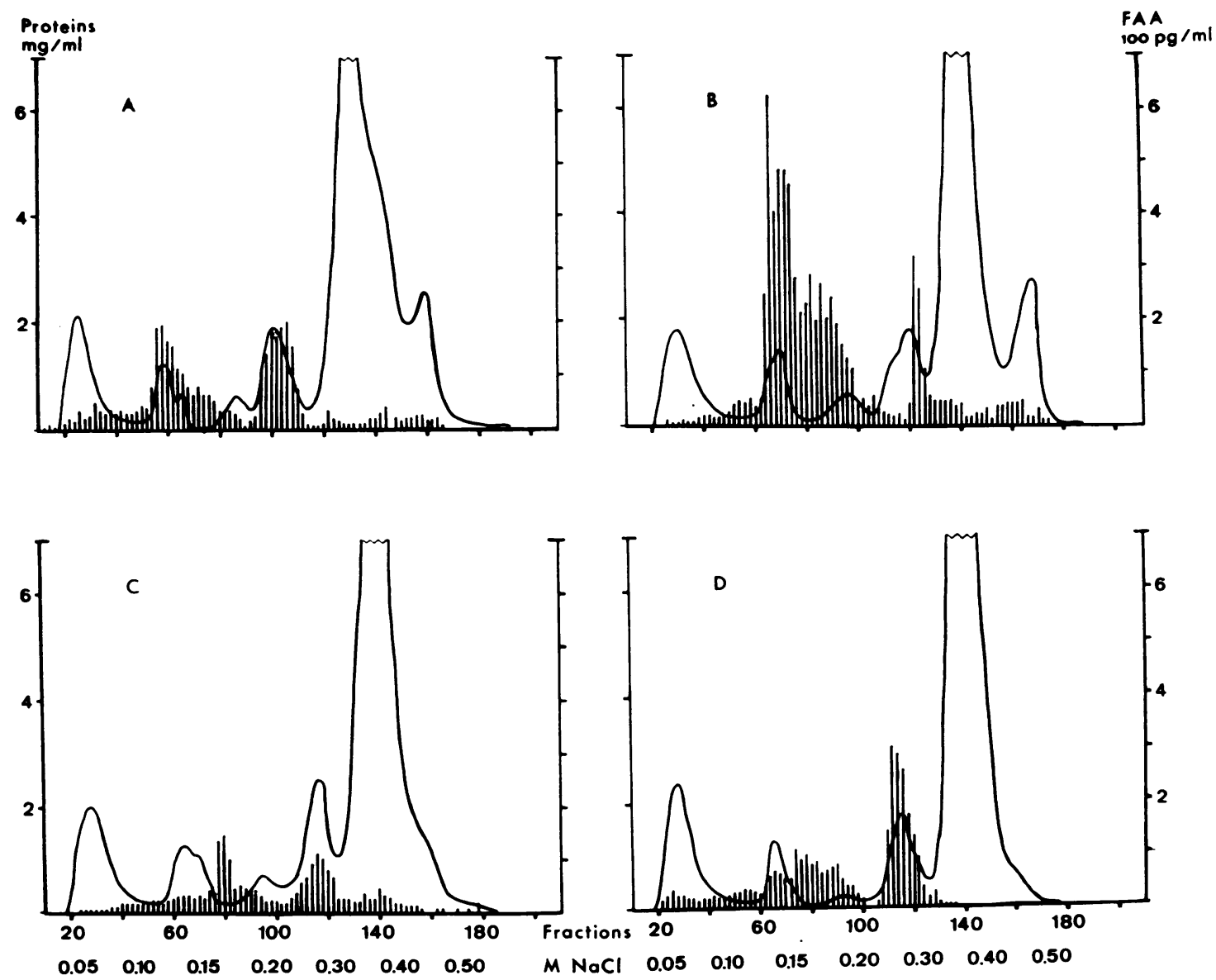

Fig 3 Chromatograms of a 20-year-old primipara P.T. The first $(A)$ was taken after the 20th and the second $(B)$ after the 30th week of gestation. The third $(C)$ and fourth $(D)$ were taken five days and eight weeks after delivery.

but no neuropathy (fig 5): the total serum folic acid activity fell from 6.9 (fig $5 \mathrm{~A}$ ) to $2.5 \mathrm{ng} / \mathrm{ml}$ (fig $5 \mathrm{C}$ ) at the same time as the binding percentage rose from 30 to 56 . No changes occurred in zone I. The amount of folic acid activity bound to zone II fell from 72 (fig $5 \mathrm{~A}$ ) to 31 (fig $5 \mathrm{C}$ ) \%. In zone III, a slight increase in binding, from 4 (fig $5 \mathrm{~A}$ ) to 13 (fig $5 \mathrm{C}$ ) $\%$, took place. Also in zone IV, an increase from 59 to 84 was noted. Zone $\mathrm{V}$ remained unchanged. Pernicious anaemia with neuropathic changes responded to treatment as follows: total serum folic acid activity fell from 18.4 (fig $6 \mathrm{~A}$ ) to 4.8 (fig $6 \mathrm{C}$ ) $\mathrm{ng} / \mathrm{ml}$. At the same time, the degree of binding rose from 5 to $38 \%$. In zone I it increased slightly, and also in zone II (fig 6 B-C). Zone III showed no change, nor were any distinct changes seen in zones IV and V. On the whole, this patient's chromatogram was very much like a normal subject's, and no major changes occurred during therapy (fig $6 \mathrm{~B}-\mathrm{C}$ ).

In those using diphenylhydantoin the binding of folic acid activity to serum increases in the protein zone. In two of three patients, folic acid activity was bound to proteins (table III). Some was noted in zone I, and a marked increase in zones II-III, whereas there was less in protein zone IV than in normal chromatograms.

\section{Discussion}

The results of the present study show that in these laboratory conditions the natural folic acid activity in the chromatograms of the sera of healthy people is eluted in at least three maxima in the protein zone. The first distinct maximum is eluted with protein 

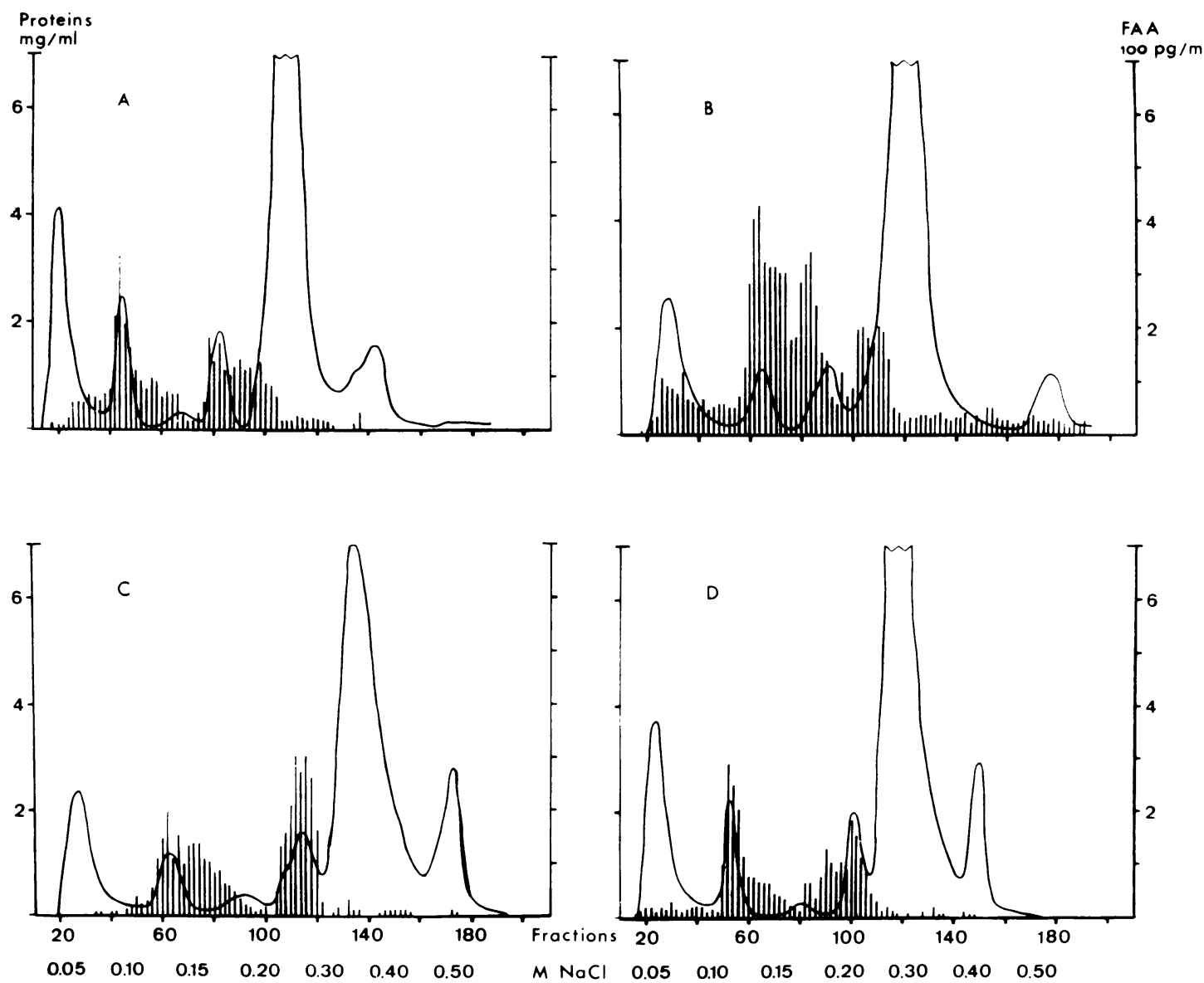

Fig 4 Chromatograms of a 29-year-old primipara T.V. A-B during pregnancy, C-D after delivery as in figure 3.

zone II, the second with zone III, the third with zone IV, and the balance with zone V. Distinctive folic acid activity is seldom seen in zone I. Slightly less than half the total folic acid activity is eluted with serum proteins, and the remainder leaves the column considerably later than the proteins (the so-called unbound folic acid activity). Studies during pregnancy, during the treatment of pernicious anaemia, and during medication with diphenylhydantoin revealed that great changes occur not only in the amount of total folic acid activity but also in the proportions of variously bound folic acid activities. These observations concerning the metabolism of folic acid activity are probably new, and if they can be confirmed in a larger number of subjects and prove to be specific to some particular factor, they may be of value in the re-assessment of the whole metabolism of folic acid activity.
Sephadex gels are well suited for the separation of bound folic acid activity from free folic acid activity. Sephadex G-25 separates proteins and the bound rapidly from the free folic acid activity fraction but by its means bound folic acid activity cannot be refractionated. This refractionation was tried in our laboratory with hydroxyapatite (Bio-gel HT) and Sephadex G-200, but these cannot separate sufficiently well the alpha-2-macroglobulin zone from the albumin zone. For this purpose, we developed the modification described at the beginning of the present paper, in which the $\mathrm{NaCl}$ gradient system seems to be particularly well adapted for the separation of the different fractions of folic acid activity. The basic condition for successful separation is, however, that the equipment used should be as aseptic as possible, all the solutions sterilized, and that the procedure should take place in cold conditions, in a closed and, as far as possible, 

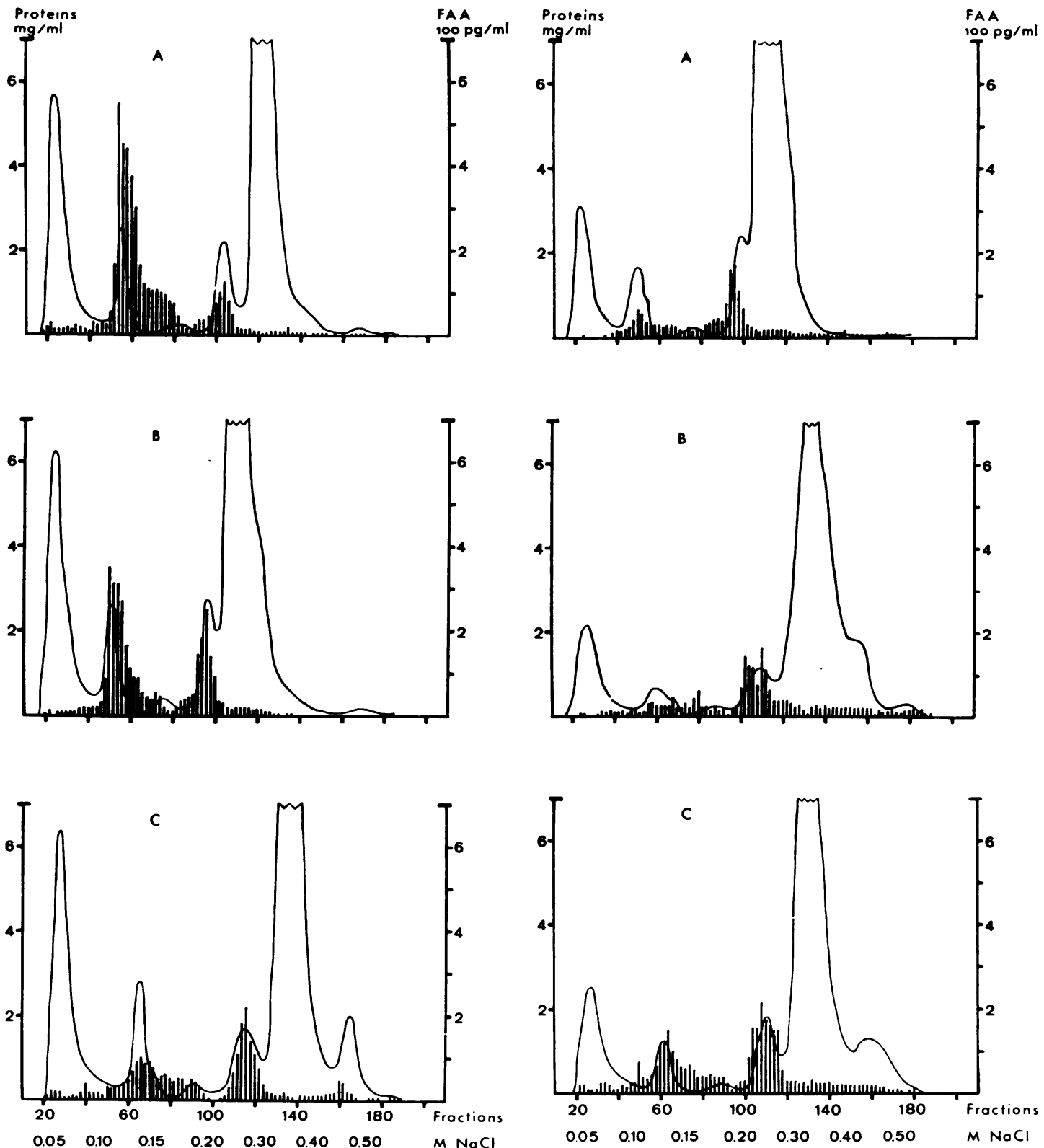

Fig 5 Chromatograms of a 51-year-old man with pernicious anaemia (V.H.) (no neuropathic symptoms) A before the start $(\mathrm{Hb} 82 \mathrm{~g} / \mathrm{l})$ of treatment $(1000 \mu \mathrm{g}$ vitamin $B_{12}$ twice a week), chromatogram B two weeks later ( $\mathrm{Hb} 130 \mathrm{~g} / 1)$, and chromatogram $\mathrm{C}$ seven weeks later (Hb $143 \mathrm{~g} / 1)$.

Fig. 6 Chromatograms of the 69-year-old man with pernicio us anaemia (Y.A.) with pronounced symptoms of neuropathy in the limbs, A before start of treatment (treatment as above) (Hb 86 g/I), chromatogram B two weeks later ( $\mathrm{Hb} 116 \mathrm{~g} / 1)$, and chromatogram $\mathrm{C}$ seven weeks later ( $\mathrm{Hb} 138 \mathrm{~g} / \mathrm{l})$. 


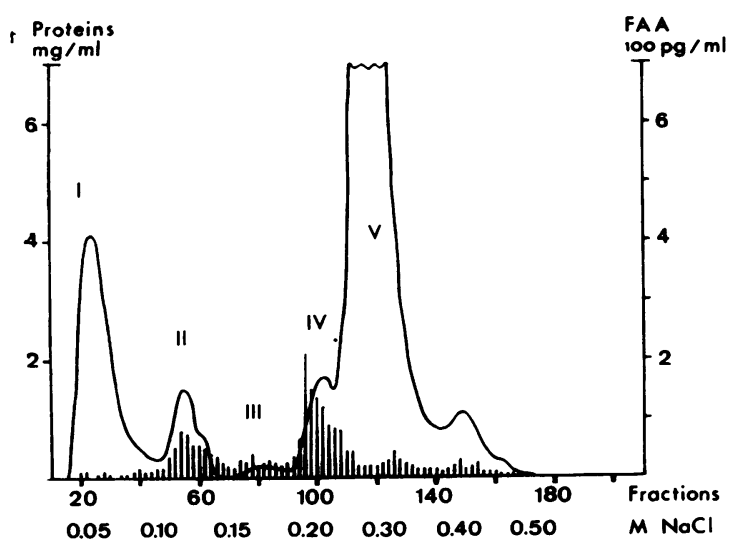

Fig 7 Typical picture of the chromatogram of a diphylhenydantoin user, a woman of 22, serum DPH level $0.7 \mathrm{mg} / 100 \mathrm{ml}$.

\begin{tabular}{|c|c|c|c|}
\hline \multirow[t]{2}{*}{ Protein Zones } & \multicolumn{3}{|c|}{ Patients } \\
\hline & 1 & 2 & 3 \\
\hline \multicolumn{4}{|l|}{ Whole Serum } \\
\hline Proteins $(\mathrm{mg} / \mathrm{ml})$ & $85 \cdot 2$ & 62.4 & $66 \cdot 2$ \\
\hline FAA (ng/ml) & $2 \cdot \overline{2}$ & $4 \cdot 7$ & $2 \cdot 6$ \\
\hline FAA/protein (ng/g) & $27 \cdot 4$ & $34 \cdot 0$ & $39 \cdot 8$ \\
\hline $\begin{array}{l}\text { Protein-bound FAA (\%) } \\
\text { Zone I }\end{array}$ & 100 & 42 & 100 \\
\hline \multicolumn{4}{|l|}{ Zone I } \\
\hline Proteins (\%) & 18 & 11 & 12 \\
\hline FAA (\%) & 18 & 5 & 9 \\
\hline $\begin{array}{l}\text { FAA/protein (pg/mg) } \\
\text { Zone II }\end{array}$ & 28 & 17 & 30 \\
\hline \multicolumn{4}{|l|}{ Zone II } \\
\hline Proteins ( $\%)$ & 8 & 6 & 7 \\
\hline FAA $(\%)$ & 21 & 55 & 66 \\
\hline FAA/protein (pg/mg) & 78 & 322 & 393 \\
\hline \multicolumn{4}{|l|}{ Zone III } \\
\hline Proteins (\%) & 2 & 1 & 3 \\
\hline FAA $(\%)$ & 13 & 3 & 12 \\
\hline FAA/protein (pg/mg) & 173 & 96 & 173 \\
\hline \multicolumn{4}{|l|}{ Zone IV } \\
\hline Proteins $(\%)$ & 9 & 14 & 5 \\
\hline FAA (\%) & 23 & 26 & 8 \\
\hline FAA/protein (pg/mg) & 68 & 65 & 61 \\
\hline \multicolumn{4}{|l|}{ Zone $V$} \\
\hline Proteins (\%) & 63 & 73 & 73 \\
\hline FAA $(\%)$ & 24 & 10 & 4 \\
\hline FAA/protein (pg/mg) & 10 & 5 & 2 \\
\hline
\end{tabular}

Table III Chromatography results in three female patients who had taken DPH, $300 \mathrm{mg} /$ day, for a minimum of one year. Diphenylhydantoin contents of the serum: $0 \cdot 7,1 \cdot 6$, and $2 \cdot 6 \mathrm{mg} / 100$

the most germ-free space. Interest has earlier been aroused by the question as to why the catch of folic acid activity obtained from the column exceeded the amount applied (Retief and Huskisson, 1970). According to the experience of our laboratory the chromatography column is very easily infected, and if it is the folic acid activity produced by various microbes spoil the whole attempt at separation. After the run is completed the catch is really much greater than the amount applied to the column. Aerobacter aerogenes, present in the laboratory air, produces folic acid activity in particular abundance (our unpublished observation).

The DEAE Sephadex A-50 gel column used in the present work is particularly well suited for the separation of folic acid activity in the protein zone. Its use requires a lengthy routine and working with it is time-consuming. No mass examinations, therefore, can enter into the question. The use of an electric field for the separation of folic acid activity, although free folic acid activity was eliminated in advance, $\tilde{\sigma}$ does not seem suited for a study of this type (Markkanen, Virtanen, Himanen, and Pajula, 1972). No protective agents seem to enter into the question in chromatography since they seem to split folic acid activity off its bonds (Markkanen, 1968). The serum used for chromatography must be absolutely fresh, for storage for even a few days changes the natural picture (unpublished observation). Fractions must also be determined immediately after elution, for $\omega$ otherwise bacterial infections tend to increase greatly the folic acid activity content of the fraction (unpublished observation), which in turn naturally increases the total catch from the column (erroneously). We have found that the repeatability of the chromatographic results is excellent with the same test person in exactly the same test conditions. This in our opinion is an important basis which makes it possible to study, on the whole, the effect of certain physiological or pathophysiological factors.

It is now very widely known that the total serum folic acid tends to fall during pregnancy, whether this be taken as a sign of the development of deficiency or as a regular physiological occurrence. In this preliminary study we have been able to show that at least an equally drastic change in the binding ratios of folic acid activity occurs with advancing $\rightarrow$ pregnancy, and a very fast reversal towards normal after delivery. It was earlier assumed that $N$ unbound folic acid activity was required to safeguard the developing foetus, while some free folic acid $\mathcal{N}$ activity was excreted into the urine owing to the $\omega$ accelerated glomerular filtration rate (Fleming, 1972). The free folic acid activity excreted through the skin probably also deserves attention. These $\mathbb{D}$ factors, however, hardly explain the change which ? takes place in the protein binding of folic acid 0 activity, which again after delivery rapidly turns $\frac{\mathrm{O}}{\mathbb{D}}$ towards normal. Above all, chromatograms should $\stackrel{\rho}{\rightarrow}$ be carried out more often and during a longer period $\AA$ after delivery so that the causal connexions may be $\overline{2}$ better clarified. We have already made a preliminary study of the efficacy of contraceptive hormones in 
this respect. The changes are in any case less pronounced than during pregnancy, if there are any at all while oral contraceptives are being taken (unpublished observation).

Concerning the interrelationship of pernicious anaemia and folic acid activity, it is known that its administration can unspecifically improve the anaemia but at the same time worsen the neurological symptoms (Ross, Belding, and Paegel, 1948, and others). Raised serum values are sometimes recorded in pernicious anaemia (Waters and Mollin, 1963, and others). Administered methyl-tetrahydrofolate was eliminated more slowly from the blood of the pernicious anaemia patients than of the controls (Nixon and Bertino, 1972, and others). To date, further investigations into the subject are based on assumptions alone. The present study showed that there is a decided difference between the binding of folic acid activity to proteins in the untreated patient with pernicious anaemia and in a healthy control. The chromatogram of folic acid activity showed a definite improvement while vitamin $\mathrm{B}_{12}$ was being given (fig 5). The chromatogram for the pernicious anaemia patient with myelopathy is close to normal, but before treatment most of the total serum folic acid activity is in the unbound form. This patient had a fairly high total serum folic acid activity, a finding reported also by Chanarin and McLean (1967) in connexion with myelopathy. The changes in the binding of folic acid activity are extremely interesting in pernicious anaemia but so far, in the absence of continued studies, they are difficult to explain. The connexion between neuropathy and especially the change in binding require further study.

The relationship between deficiency of folic acid activity and the administration of diphenylhydantoin is well known. It has been assumed that diphenylhydantoin released the folic acid activity from its protein bonds (eg, Klipstein, 1964). Aspirin has also been accused of the same thing (Alter, Zvaifler, and Rath, 1971). According to the present study, the total serum folic acid activity seems to decrease but the binding increases, mainly in the transferrin zone. Slight loss is also noted in protein zone IV.

The changes in binding may be assumed to be projected to liver functions. This is suggested by the fact that transferrin, which is primarily involved in the change of binding, is largely synthesized in the liver. The way in which the other serum proteins are coupled to the chain of folic acid activity metabolism remains to be seen in the later experiments.
It seems that the use of labelled folic acid activity in these experiments would be very useful, especially if chromatography, in animal experiments, could be carried out serially on sera and livers in the various phases of folic acid metabolism.

\section{References}

Alter, H. J., Zvaifler, N. J., and Rath, C. E. (1971). Interrelationship of rheumatoid arthritis, folic acid, and aspirin. Blood, 38, $405-416$.

Banerjee, D. K., and Chatterjea, J. B. (1971). Observation on the lability of serum whole blood and R.B.C. folates of human blood. Indian J. med. Res., 59, 369-376.

Chanarin, I., and McLean, A. (1967). Origin of serum and urinary methyltetrahydrofolate in man: some observations on the methylfolate block hypothesis in Addisonian pernicious anaemia. Clin. Sci., 32, 57-67.

Condit, P. T., and Grob, D. (1958). Studies on the folic acid vitamins I. Observations on the metabolism of folic acid in man and no the effect of aminopterin. Cancer (Philad.), 11, 525-536.

Elsborg, L. (1972). Binding of folic acid to human plasma proteins. Acta haemat. (Basel), 48, 207-212.

Fleming, A. F. (1972). Urinary excretion of folate in pregnancy. $J$. Obst. Gynaec. Brit. Cwlth, 79, 916-920.

Grogan, C. H., and Roboz, E. (1955). Simple apparatus for concentrating biologic fluids of low protein contents. J. Lab. clin. Med., 45, 495-498.

Hitzig, W. H., Butler, R., Cottier, H., Hess, M., and Muralt, G. V. (1963). Die Plasmaproteine in der klinischen Medizin. Springer, Berlin.

Johns, D. G., Sperti, S., and Burgen, A. S. V. (1961). The metabolism of tritiated folic acid in man. J. clin. Invest., 40, 1684-1695.

Klipstein, F. A. (1964). Subnormal serum folate and macrocytosis associated with anticonvulsant drug therapy. Blood, 23, 68-86.

Markkanen, T. (1968). Pteroylglutamic acid (PGA) activity of serum in gel filtration. Life Sci., 7, 887-895.

Markkanen, T., and Peltola, O. (1971). Carrier proteins of folic acid activity in human serum. Acta haemat. (Basel), 45, 106-111.

Markkanen, T., Virtanen, S., Himanen, P., and Pajula, R.-L. (1972). Transferrin, the third carrier protein of folic acid activity in human serum. Acta haemat. (Basel), 48, 213-217.

Neal, G. E., and Williams, D. C. (1965). The fate of intravenously injected folate in rats. Biochem. Pharmacol., 14, 903-914.

Nixon, P. F., and Bertino, J. R. (1972). Impaired utilization of serum folate in pernicious anemia. J. clin. Invest., 51, 1431-1439.

Raunio, V. (1968). Characterization of glycosidases by immunoelectroforesis. Acta path. microbiol. scand., Suppl., 195.

Retief, F. P., and Huskisson, Y. J. (1969). Serum and urinary folate in liver disease. Brit. med. J., 2, 150-153.

Retief, F. P., and Huskisson, Y. J. (1970a). Folate binders in body fluids. J. clin. Path., 23, 703-707.

Retief, F. P., and Huskisson, Y. J. (1970b). Possible folate binders in body fluids. In Abstract Volume of the International Congress of Haematology, Munich, August 1970, p. 376.

Ross, J. F., Belding, H., and Paegel, B. L. (1948). The development and progression of subacute combined degeneration of the spinal cord in patients with pernicious anemia treated with synthetic pteroylglutamic (folic) acid. Blood, 3, 68-74.

Sevitt, L. H., and Hoffbrand, A. V. (1969). Serum folate and vitamin $\mathbf{B}_{12}$ levels in acute and chronic renal disease. Effect of peritoneal dialysis. Brit. med. J., 2, 18-21.

Toennies, G., Usdin, E., and Phillips, P. M. (1956). Precursors of the folic acid-active factors of blood. J. biol. Chem., 221, 855-863.

Uriel, J. (1964). The characterization reactions of the protein constituents following electrophoresis or immunoelectrophoresis in agar. In Immuno-electrophoretic analysis, edited by P. Grabar and P. Burtin, pp. 30-57. Elsevier, Amsterdam.

Waters, A. H., and Mollin, D. L. (1963). Observations on the metabolism of folic acid in pernicious anaemia. Brit. J. Haemat., 9, 319-327.

Wieme, R. J. (1965). Agar Gel Electrophoresis. Elsevier, Amsterdam. 